\title{
What makes you not a Buddhist?: A preliminary mapping of values
}

\section{Phra Nicholas Thanissaro}

Postgraduate Research Student: Warwick Religions and Education Research Unit

Correspondence: WRERU, Institute of Education, Unviersity of Warwick, Coventry CV4

7AL, UK

Email: p.n.thanissaro@warwick.ac.uk.

\section{The Author}

Phra Nicholas Thanissaro is a postgraduate research student at the University of Warwick's Institute of Education. He has been funded until 2015 by a Warwick Postgraduate Research Scholarship to conduct research on Buddhist adolescent identity and religiosity in the UK. A Buddhist monk affiliated with the Dhammakāya Foundation, he holds a Masters degree from the University of Warwick and a Postgraduate Certificate of Education from Manchester Metropolitan University. 


\section{Abstract}

This study sets out to establish which Buddhist values contrasted with or were shared by adolescents from a non-Buddhist population. A survey of attitude toward a variety of Buddhist values was fielded in a sample of 352 non-Buddhist schoolchildren aged between 13 and 15 in London. Buddhist values where attitudes were least positive concerned the worth of being a monk/nun or meditating, offering candles \& incense on the Buddhist shrine, friendship on Sangha Day, avoiding drinking alcohol, seeing the world as empty or impermanent and Nirvana as the ultimate peace. Buddhist values most closely shared by nonBuddhists concerned the Law of Karma, calming the mind, respecting those deserving of respect, subjectivity of happiness, welfare work, looking after parents in old age and compassion to cuddly animals. Further significant differences of attitude toward Buddhism were found in partial correlations with the independent variables of sex, age and religious affiliation. Correlation patterns paralleled those previously described in theistic religions. Findings are applied to spiritual, moral, social and cultural development and for the teaching of religious to pupils of no faith adherence. The study recommends that quantitative psychometrics employed to conceptualize Buddhist values by discriminant validity in this study could be extended usefully to other aspects of the study of Buddhism, particularly in quest of validity in the conceptualization of Buddhist identity within specifically Buddhist populations.

\section{Keywords}

adolescents, spiritual attitudes, Buddhist religiosity, values mapping 


\section{What makes you not a Buddhist?: A preliminary mapping of values ${ }^{1}$}

The relative scarcity with which Buddhism is mentioned in the British Religion in Numbers database $\mathrm{e}^{2}$ or a variety of academic journals of religious research emphasizing quantitative methods, ${ }^{3}$ confirms Wallace's $(2007,78)$ observation that Buddhism ${ }^{4}$ is under-represented in quantitative research relative to Christianity and Islam. The lack may be caused simply by Buddhist scholars being unfamiliar with this methodology of research or it may involve some resistance on behalf of Buddhists themselves. Since study of Buddhism, no less than for research on other subjects (Kelly 2006), should be defined to a significant degree through critical discourse between researchers and the community of its practitioners, the apparent differences of opinion concerning methodologies are important for this article to reconcile before presenting its own quantitative study of attitudes to Buddhism. This article starts by justifying why quantitative methods have been chosen to explore the nature of Buddhist religiosity defending the theoretical assumptions underlying these methods in a way that hopefully reassures practitioners of Buddhism that potential findings in no way detract from the emancipatory benefits of the research. The article continues by presenting a study in discriminant validity concerning Buddhist identity - in more layman's terms as an exploration of 'what makes a person not a Buddhist'. This article consists of three parts. Part one reconciles Buddhist studies with the use of quantitative methodologies of research. Part two presents a quantitative study of adolescent attitudes to Buddhism. Part three discusses the contribution of this study to understanding Buddhism while suggesting guidance in the application of findings to enactable policy and practice.

The contribution this article makes to knowledge, apart from bridging the aforementioned methodological gap, is to help to bring Buddhism into dialogue with the psychologies of religion and individual differences. The quantitative study presented 
here maps the boundaries and overlaps of Buddhist values into the attitudes of nonBuddhists. Correlation of results by sex, age and religious affiliation help clarify the degree to which these factors can account for observed value patterns.

\section{Part 1: Reconciling Buddhist Studies with Quantitative Methodologies}

\section{Some Key Terms}

The key term to define when justifying the use of quantitative data in measuring Buddhist religiosity is 'validity' which means the extent to which an instrument measures or correlates with the theorized scientific construct it purports to measure (Pennington 2003, 37) - in this study, the relevant construct is Buddhist religiosity, or religiosity unique to Buddhists. Validity can be divided into several components - four of which are of direct relevance here. Construct validity is concerned with examining how the operational form of the construct works in the light of theory. Face validity is what an instrument superficially appears to measure - often what 'seems valid' to the investigator - but which needs to be tested additionally against the views of a panel of experts or a representative sample of the respondents or target audience. This aspect of validity is often a good starting point for research, but in social science, on its own, is not a secure predictor of validity. Content validity is the extent to which a measure represents all facets of a social construct. Discriminant validity [or in some places 'divergent' validity (Cooper 2002, 60)] is the degree to which an operation that is not similar to other operations it theoretically should not be similar to.

Triangulation, from the point of view of scientific research, has been described as 'an attempt to map out or explain more fully, the richness and complexity of human behaviour by studying it from more than one standpoint' (Cohen et al. 2007, 141). Four types of triangulation can help make scientific measurement more trustworthy (Denzin 
1978): namely, data triangulation (mixing of data types); investigator triangulation (interresearcher reliability); theory triangulation (a dataset can be triangulated against itself [without being a tautology] e.g. positioning theory versus deductive approach); and methodological triangulation (multimethod research). In this piece of research, triangulation has been ensured through methodological means - namely through the hermeneutic cycle between quantitative and qualitative methodologies in relation to the experimental subject matter, in keeping with Cohen et al.'s (2007) advice that methodological triangulation usually implies use of both quantitative and qualitative data. Ideally, the data from the qualitative research should feed into the survey instrument used for the quantitative research, generating data, which, in turn, provide further detail on, and refer back to, data from the qualitative research in a hermeneutic cycle of enquiry. In 'top-down' research, the cycle starts with a researcher's a priori framework, often with predetermined categories to be tested experimentally. If the hermeneutic cycle of study starts from the premise of an entirely participant-generated agenda, such triangulation can be said to be based in 'grounded theory' (Glaser and Strauss 1967). In 'bottom-up' research, especially grounded theory, categories emerge through examination of the data.

The term 'hermeneutic cycle' usually implies moving back and forth between individual and group in anthropology or between the specific and the general in textual analysis - but in this article the term is taken to mean the process of methodological triangulation between alternative application of quantitative and qualitative interrogation of data. In practice, it is rare to find research entirely divorced from some sort of a priori researcher-imposed conceptual framework - and realistically a final text can be regarded as 'negotiated' between researcher and participant viewpoints (Clifford 1997, 210). 
There are many different approaches to psychology, but given that the study of psychology can focus on the respects in which a person is like all other people, like some other people or like no other people (Kluckhohn et al. 1953, 53), the individual differences approach to psychology locates itself within 'differential psychology' i.e. the ways in which a person is like 'some other people'. It is an approach that remains mindful of the important variation between individuals that can be masked by averaging and is based on an assumption that human behaviour is not entirely random but has discernable patterns to it and that deeper and more covert organizing factors can be accessed and measured by appropriately devised psychometric instruments (Francis 2009, 127-8). The approach is more widely known for aptitude psychometrics and predicting differences and similarities in human thought, emotionality and behaviour (Chamorro-Premuzic 2007, 2).

Finally, from the point of view of operational definitions of religious affiliation, respondents are labelled 'non-Buddhist' because given the chance to self-identify their religious affiliation, all chose non-Buddhist affiliations. Although such labling is potentially vulnerable to nominalism, psychologists of religion continue to consider self-assigned affiliation a significant dimension of religiosity (Fane 1999) - although not necessarily a secure proxy for other dimensions of religiosity, such as belief or practice.

\section{What scientific research has become in the early years of the $21^{\text {st }}$ Century}

The nature of scientific enquiry has changed under the influence of post-positivism and the resulting balance between the paradigms of empiricism and interpretivism has resulted in that of critical realism. Far from its former monolithic status (Garrison 1986), scientific enquiry at the beginning of the $21^{\text {st }}$ Century is considered provisional 
and no longer encourages a culture of science that accepts certainty (Erickson and Gutierrez 2002, 22; Hartas 2010, 23). Social sciences, often provide data that is no more than a snapshot with a generalizability that has a short 'half-life' - perhaps lasting only until a new experimental paradigm comes along (Berliner 2002, 20). It is tempting to believe that pieces of research will tie up loose ends but this is not always the case where respect for ethical correctness toward participants might be more important than experimental results. To give an example, sometimes where consent from schools concerning access to participants is not sufficiently forthcoming, this might have an important adverse effect on the sample size (Kay and Smith 2001). Sometimes work is deemed preliminary because it is exploratory. The word 'preliminary' does less to detract from the worth of research than highlight a subject area for the attention of more detailed future research. Where research in education has been criticized it is not because it has been small in scale, but because it has been partisan, methodologically problematic, non-empirical or lacking in relevance or impact (so-called 'blue skies' research)(Tooley and Darby 1998). Furthermore, scientific rigour might demand that the object of research be mapped both by a process of confirmation and elimination, since the deductive processes of science are often most powerful when employing a process of elimination to explore possibilities - leaving no conceptual stone unturned until due effort had been made to disprove a hypothesis. Science tends to progress through research that falsifies rather than confirms theories (Popper 1963). Hence, trying to find what is unique to Buddhists by looking at the values shared with a nonBuddhist population (a process of elimination) would be considered an essential part of due diligence in ascertaining construct validity - since identity boundaries between religions are expected to be fuzzy and to some extent permeable. With an indication of what makes values less exclusively Buddhist (i.e. by taking a selection of values that at 
face value relate to Buddhism and identifying which are also popular with nonBuddhists), it might become easier to pin down, by elimination, what makes values particular to Buddhists. Lastly readers may need reminding that to fit concepts to a scientific framework is not the only important criterion for academic endeavour, since theory formation outside the scientific framework can also be considered valuable if it can be shown to be comprehensive, parsimonious or of applied value (Pennington 2003, $15)$.

\section{Known benefits of quantitative research methodologies}

Nonetheless, there are known advantages to making studies quantifiable where possible. Employing quantitative methodologies for research on Buddhism has several advantages which include obtaining results that are repeatable, being generalizable, being able to handle both objective and subjective data, going beyond face validity and minimizing effects of observer bias

Experiments involving quantitative methods are more amenable to repetition than qualitative investigations. Since characteristics of participants such as sex, ethnicity, age or religious affiliation can be quantified, the experiment can be repeated on another sample with the same characteristics and a similar result would be expected. Successive waves of research can validly build upon one another. The ability to control for personal characteristics in this way is not available in qualitative research where each study may represent a unique instance of social behaviour.

Quantitative methodologies facilitate generalization from results. Given an adequate and representative sample $\operatorname{size}^{5}$ results can be extrapolated from the experimental sample to a larger population possessing the same personal characteristics. 
Quantitative data isn't necessarily synonymous with objective measures - in fact it can sometimes imply the opposite - generating figures from subjective data. In the case of domestic heating, for example, 'heat comfort' could be quantified instead of 'temperature' in applications where it is how warm people feel that matters rather than the temperature per se (as would be important for other applications such as storage of foodstuffs or seeds). Quantitative measure can reveal counter-intuitive experimental effects and allow latent or subconscious processes to be deduced from manifest measurable qualities. Such measures can be useful in cases where participants themselves are not self-aware concerning the underlying processes in the mind that affect their decisions; by quantitative analysis, factors can be teased out in a way that goes beyond face validity. Quantitative methods are thus a useful research tool in personality psychology where reliance on self-report (the phenomenological approach) is notoriously unreliable (Cooper 2002, 7-8).

In triangulation with qualitative data, quantitative data may help to overcome constrictive worldviews of observers locked into outsider paradigms with reference to Buddhism (Choompolpaisal 2008) or blinkered views as insiders. Worries about observer bias common in ethnological techniques (Clifford and Marcus 1986) are less of an issue in a mixed-methods design such as that of the present research study. In the matter of scale construction, the benefits of involving one or more insiders at the design stage is likely to outweigh any possible disadvantages due to observer bias (Thanissaro 2010d, 72). Being an insider to Buddhism, rather than causing objectivity to be lost, should help overcome many of the possible limitations non-Buddhist researchers face when trying to 'bracket out' non-Buddhist presuppositions. Since the usual way to bracket out assumptions is to engage with the participants by means of edification and empathy, an insider would be better qualified to do this - by entering the authentic 
mindset of a Buddhist (Smart 1987, 4). If the present research had been based on more qualitative, reflexive data, the 'partial, selective and personal' nature of observations (Brewer 2000, 44-45) might deserve the concern about objectivity voiced by Pracharart $(2004,33)$ in a similar capacity, when undertaking recent participant observation in UK Buddhist temples - but the beauty of quantitative surveys is that experimenter influence can be minimized by delegating the administration of surveys to a helper.

\section{Known Shortcomings of quantitative research methodologies}

Despite the aforementioned strengths of quantitative methodologies, reliance on solely quantitative methodologies may have weaknesses which researchers need to take into account. Possible shortcomings of quantitative research methodologies (for young people in Buddhism) may include the following: glossing over sectarian differences, being insufficiently nuanced to understand young people, being limited to correlations rather than elucidating causes and effects, lack of perspective on long-term processes such as nurture or development, the temptation to unreasonable extrapolation (reification) and anomalies where respondents consistently misunderstand survey questions. After expanding on each of these possible criticisms, I will go on to mention how, in this study, I have attempted to minimize the shortcomings.

There is the danger of being tied into a particular sectarian standpoint within Buddhism which may not be apparent to outsiders. There is sometimes a sectarian temptation to sneak a 'favourable' answer into the question or skew representativeness of sampling. Although randomized samples have never been available to me in the true sense of clinical trials, conscious that as a particular sort of insider, I might be influenced by my own denominational allegiances, I have intentionally included a variety of denominations and challenged the accuracy of my findings using multiple 
hermeneutic cycles. At the distal end of the data processing there may also be weaknesses in the interpretation where particular answers are sought to fit with a theoretical framework fixed a priori by the researcher - so-called 'cherry picking' or 'data dredging'. Hopefully from my explanation of how the hermeneutic process has been governed by mixed-methods triangulation, it will be evident how observer interpretation has been minimized and that construction of the survey has been neither arbitrary, manipulated or based on anecdotal materials.

With young people, the exclusive use of quantitative research methods is thought potentially misleading as many of their distinguishing characteristics are subtle and nuanced (Andolina et al. 2002). The critical realism paradigm of research and enquiry to which this study belongs is one of the main defenders of the idea that social enquiry can be scientific (Kemp and Holmwood 2003, 165). In researching young people, I have made a consistent effort to draw on the strengths of both quantitative and qualitative methodologies as recommended by that paradigm.

Another limitation of much quantitative research is that it relies on correlation. Although it can detect if phenomena are linked statistically, the direction of causality cannot be ascertained without some sort of experimental intervention. Also it should be conceded that, of the seven aspects concluded by Ninian Smart (1992), ${ }^{6}$ only four aspects of religiosity have proved amenable to quantitative measure within individual differences psychology - namely, affiliation, belief, attitude and practice - and even these have only proved measurable giving them operational definitions (Hood et al. 2009, 11-12). Furthermore, quantitative methodologies provide snapshots of social phenomena, but may lack perspective on the longer term processes at work. In my own research, including this article, I have thus made no claims about development or nurture. 
Anomalies may also arise in the conceptualization of religiosity if quantitative results are extrapolated or generalized beyond the populations in which they have been conceived. In recognition of this danger, for the measurement of attitude toward Christianity, Francis (1978) describes how he performed 'due diligence' in the initial survey design by shortlisting from 110 possible questions down to 24 . The original questions appear to have been constructed by identifying the most important objects of faith for each religion (presumably chosen by affiliates of that religion) which were then used to construct statements or their reverse-coded equivalents - for Christianity, this formula yielded positive and negative statements on God, Jesus, the Church, the Bible and prayer. This worked well for Christianity because statements were shortlisted by an insider starting with many Christian-generated questions and using statistical methods to shortlist down to the most powerful questions in terms of reliability. ${ }^{7}$ Generally, analysis of reliability will select for questions that are clear and unambiguous, by drawing on multiple measures per object of enquiry and by being able to move towards a clearly defined construct for each scale - but this vouches only for the technical consistency of questions without guaranteeing that the questions have identified valid aspects of religiosity. ${ }^{8}$ When measuring attitude toward religion, as more generally, it is debatable how far it is acceptable to extrapolate results. When extrapolating measures of religiosity by a common scale across different Christian denominations, few anomalies would be expected. However, when extrapolating between Christianity and Hinduism, the anomalies might be more apparent since the accuracy with which Hinduism can be conceptualized is reduced, if forced into a monotheistic framework (Delmonico 2004, 32). Jackson and Nesbitt (1993) have demonstrated the complications inherent in generalizing even within the Hindu religious tradition. As it is not clear whether the Francis-Santosh Scale of Attitude toward Hinduism (Francis et al. 2008) was designed 
by a process of shortlisting from many grounded questions, ${ }^{9}$ it is possible that considerable intra-religious diversity ${ }^{10}$ may have been overlooked - hence, any unidimensionality assumed in the dataset might be an external imposition. Although what is measured may be internally consistent (i.e. reliable) this is no guarantee that the content validly reflects Hindu religiosity. It may, for example, be measuring a 'monotheist tendency' in Hindus that might correlate statistically with other aspects of their practice. For Buddhism the effect is likely to be yet more pronounced as the theistic element is altogether missing. In short, reified views of religion, especially Buddhism, may result from the assumption, even for measurement of attitude toward religion, that religions share a common structure. For this reason, rather than the extrapolating from scales of attitude from other religions, I have consistently gone back to grounded qualitative data Buddhists themselves have generated when devising survey questions.

Lastly, there is the problem of respondents understanding survey questions differently than the researchers have anticipated. If a question is worded so that it is consistently misunderstood by young participants (for example, a researcher might understand the word 'wicked' in a different way from a young person) such a question might not fail in terms of reliability, but it would lead to invalid conclusions being drawn from data. By contrast, if a badly worded question creates confusion amongst the participants, the question will merely increase random error. In my research, the questions were piloted on a small number of respondents of the same age-group before the start of the survey, to minimize any effects of Buddhist jargon, to estimate time for completion and to make sure wording was unambiguous (which means that the participants claimed to have understood all the questions - even terms such as ‘ultimately empty' and ‘impermanence'). 


\section{Resistance to quantitative methods in Buddhist research}

In spite of precautions taken to avoid anomalies in quantitative methodologies, there are still several objections Buddhists seem to hold against studying Buddhism quantitatively. ${ }^{11}$ At the time of writing, the field of Buddhist studies has been largely dependent on non-empirical arguments and where supported empirically, have drawn largely on qualitative methodologies such as case studies, ethnology and interviews. Claims are often accepted without challenge, even when empirical evidence for them is lacking. Where quantitative data has been employed, it has often been based on relatively small sample sizes. When sweeping statements are made such as if you cannot accept four things, ${ }^{12}$ you cannot be a Buddhist' (Khyentse 2007, 4) or that Buddhism in Thailand is more 'feminine' than that of Japan (Hofstede 2001, 327) there is little to assure subsequent researchers (or the researched) that conclusions are based on anything more than anecdotal evidence. Analytic psychology, for example, has been criticised for lack of scientific rigour in its analysis of Buddhism (Yogo 2001), but these criticisms could equally well have been directed at other purely qualitative studies of the religion. In order to be scientifically acceptable (rather than metaphysics) a hypothesis un-verified by external senses (non-empirical) must at least be potentially falsifiable (the logical positivist requirement of 'verifiability theory of meaning') and it should help to form null-hypotheses from which statements can be deduced about future experiences (Carnap 1966).

The reduced dependence on interpretation implied by the use of quantitative data worries some, especially if it seems likely that the locus of expertise concerning Buddhism might be taken away from Buddhists and given to statisticians. Since the 1960s the emancipatory research paradigm based on the work of Habermas, Frieire and 
Marcuse, researchers have come to a consensus that research ought to be of benefit to the participants (Banks 2006), it is also important for me to demonstrate how the use of quantitative data continues to be of benefit to Buddhists themselves. For Buddhists, no less than for those of other religions, the spectre of vulgar positivism in Science (real or imagined) threatens to reduce the mystery of faith to (mere) figures or (perhaps more unpopularly) to a (someone else's) particular set of criteria. Psychologists of religions who have been measuring aspects of religiosity from non-Buddhist religions since the early 1960s (Glock 1962) with no 'vested' or detailed interest in Buddhist diversity have tended not to share the qualms of religious participants in their research. Nonetheless, the applied quantification of religiosity within the individual differences paradigm of psychology, has proved beneficial - especially in modelling the effect of different orientations of religiosity and different styles of religious coping toward mental health (Maltby et al. 2010, 575-6). Previous quantitative research on Buddhists in the UK (e.g. Thanissaro 2010c) can also be considered emancipatory since it is helping give voice to the values of a marginalized group in British society (although it could be argued that the same emancipation might have been achieved by research employing qualitative methodology). Thus, it would be more reasonable to consider the aims, purpose and use of research when judging its potential benefit to the participants than to object to one broad method as opposed to another on the grounds of benefit to participants. Nonetheless, the application of quantitative methods to Buddhist religiosity demands fuller apologetics than would perhaps be required by even the more critical of psychologists of religion.

Quantification is not a complete stranger to Buddhist research, however. There is a growing literature of studies which have quantified aspects of Buddhist practice - often in the applied sciences. Buddhist religiosity has been sufficiently quantifiable to be 
factored into research concerning psychiatry (Scotton 1998), alcohol abuse (Assanangkornchai et al. 2002), moral training (Pupatana 2000), psychosocial change (Thananart 2000), psychoanalytic defence mechanisms (Tori and Bilmes 2002), psychological therapy (de_Silva 1996) and learning English as a foreign language (Adamson 2003) - despite there never having been a specific study to map out Buddhist religiosity in a way that allows it to be compared with that of other religions.

Within Buddhist studies, at the more qualitative end of the quantitative-qualitative research continuum, there are scholars hesitant to settle for a particular translation of an academic text in case it threatens to reduce future possibilities for breadth of interpretation (Hubbard and Swanson 1997). At the other end of the continuum are the more positivist proponents of the Kālāma Sutta who might reject any conclusion not based on irrefutable evidence. In between come the latest social scientific paradigms and pragmatic theorists of scriptural exegesis. The philosophy of Hui-Neng ${ }^{13}$ and some Tibetan logic is no less social constructivist than the writing of George Berkeley.

In conclusion, I see no reason why Buddhism should lock itself into a particular methodology for its study. Buddhist studies as it currently stands incorporates a huge range of epistemologies - which should be no surprise, since where methodologies are to acknowledge change and complexity, multiple perspectives and discourses are required (Hartas 2010, 50-51). The essentialisms often inherent in the study of comparative religion were moderated by Wilfred Cantwell Smith who advocated avoiding the projection of terms onto other peoples' views of life - saying "No interpretation of Buddhist doctrine is valid unless Buddhists can respond 'Yes! That is what we hold'." (1981, 97). Nonetheless, there is huge potential for anomalies if structures from believing religions are projected onto traditions that like Buddhism 'do' rather than 'believe'. Instead of assuming similarities and differences, research should 
be framed through debates about quality within different sub-communities and encouragement of open discussion across epistemological and methodological boundaries (Furlong 2004, 343). Thus, rather than assuming there to be something particularly un-Buddhist about representing personal qualities by numbers it is more likely that the new landscape of Buddhist studies (Crosby 2008) has simply not yet extended this far - and my recommendation would be that Buddhist studies could beneficially extend the scope of its research in the direction of quantitative methodologies.

\section{Part 2: Research Agenda, Methodology and Findings}

Having defended the use of quantitative methods in Buddhist studies, what follows in this part of the article describes a preliminary exploration of Buddhist religiosity by quantitative methods. The research agenda was not to form a scale, as I have already published this elsewhere (Thanissaro 2011a), but to explore cross-correlations and to map values at the border of identity of those self-identifying as non-Buddhists. This part of the article builds on an initial cycle of research grounded in the experiences of Buddhist adolescents through semi-structured interviews with a preliminary small sample of Buddhist families selected from several ethnic groups and Buddhist denominations in Britain (Thanissaro 2011b). The findings from that research were used to devise attitude questions which were added to others previously designed by Smith and Kay $(2000)^{14}$ to acknowledge (but also give a fair test of) pre-existing studies, while building on their strengths. Data capture on attitude toward Buddhism was designed to investigate the intellectual aspects previously researched in Smith and Kay's work - but also the more affective aspects of Buddhism shown important by Thanissaro (2011b) such as generosity, welfare, honouring those worthy of respect, belief in the Law of 
Karma, belief in an afterlife, enlightenment, alcohol, killing animals and filial piety the last three issues having been piloted in detail - to test whether particular degrees of values were unique to Buddhists, since Cush $(1996,205)$ has suggested that aspects of Buddhism such as belief in meditation, other realms, rebirth and interconnectedness enjoy popularity even with those who would not consider themselves Buddhist. The questions were fed back into this initial round of selection of Buddhist attitude questions by elimination - trial through quantitative methods on a group of nonBuddhist adolescents in London schools (Thanissaro 2010a; b; c).

It should be conceded that at this stage, the research questions described in this article represent a provisional shortlist that is part of an abductive process leading towards a more valid set of questions to be described in forthcoming publications.

\section{Method}

\section{Sample}

Research was undertaken upon a convenience sample of 352 young people -226 males and 126 females - aged between 13 and 15 years attending London schools. Ethnically the sample included 150 whites (43\%), 105 blacks (30\%), 46 Asians (13\%), 40 of mixed race $(12 \%)$ and 5 Chinese $(1 \%)$. The sample has been characterized as nonBuddhist, because it comprised those self-identifying for religion as 149 Christians (42\%), 120 of no religion (34\%), 45 Moslems (13\%), 17 Hindus (5\%), 5 Sikhs (1\%), 3

Jews $(1 \%)$ and 13 of other ${ }^{15}$ religions (4\%). Of the pupils in the sample, $49 \%$ had studied Buddhism in their Religious Education lessons of the previous year. 


\section{Procedure and Analysis}

A multi-purpose survey [detail of which can be found in Thanissaro (2010c, 184-191)] was deployed as part of a wider research project. The survey contained biographical questions ascertaining independent variables such as age, sex and self-assigned religious affiliation adapted from Francis's (2001a) adolescent values inventory and 49 Likert five-point scale (strongly agree - agree - not certain - disagree - disagree strongly) attitude statements. ${ }^{16}$ Some of these questions might have been rejected a priori, but for this study the 'naïve' outlook of grounded theory tests questions empirically rather than making an a priori selection by face validity. Two reverse-coded statements were included in the Buddhism section, namely, "It is possible to reach salvation only through the help of God" and "I think the Buddhist festivals are based on fairy-stories" as a strategy to guard against inclusion of results from participants who had mechanically ticked the same column throughout regardless of their true attitudes.

Schools volunteered their participation in response to a circular letter from their local Standing Advisory Council on Religious Education. Surveys were delivered to participating schools in the quantities they required and administered to pupils by Year 9 and 10 teachers under examination conditions in their regular RE classes in the period January and February 2010. In keeping with constraints of ethical approval nonconsenting pupils had the option of destroying their questionnaires after completion instead of submitting them and completed surveys were kept anonymous to protect participants from having their views traced back to them. The resulting dataset was analyzed by means of the SPSS statistical package (SPSS_Inc. 1988) using the frequency and cross-tabulation routines. 


\section{Results}

\section{Overview of Attitudes to Buddhism}

Tables 1 and 2 provide an overview respectively of the highest and lowest levels of agreement with Buddhist statements amongst the non-Buddhist sample. Although the survey used a five-point continuum, for clarity of presentation, the 'agree strongly' and 'agree' responses were recoded into a single category styled 'agree' and the 'disagree strongly' and 'disagree' responses have been similarly recoded into a single category styled 'disagree'. In the ranking of Tables 1 and 2, reverse-coded statements were not included to avoid possible confusion involving double negatives.

Table 1. Agreement with Buddhist Attitude Statements (Highest Ten)

\begin{tabular}{lccc}
\hline & $\begin{array}{c}\% \\
\text { Not } \\
\text { certain }\end{array}$ & $\begin{array}{c}\% \\
\text { disagree }\end{array}$ \\
\hline I would look after my parents in their own home in their old age & 48 & 46 & 6 \\
It sickens me when cuddly animals are killed & 44 & 38 & 18 \\
If you are a Buddhist it is important to have respect for those worthy of & & 51 & 6 \\
respect & 38 & 57 & 5 \\
What goes around comes around & 37 & 58 & 5 \\
If a person does good deeds, good things will come back to them & 35 & 42 & 23 \\
I would not want to kill any sort of animal & 33 & 63 & 4 \\
Whether we enjoy life or hate it depends on how we see the world & 33 & 63 & 3 \\
I think the Buddhist idea of having a calm mind is a good one & 32 & 64 & 4 \\
Some people who have helped us a lot deserve our special respect & 29 & 67 & 4 \\
It is necessary for us to give support to the poor and needy & & & \\
\hline
\end{tabular}

As shown in Table 1, the top ten Buddhist value statements agreed with by nonBuddhists concerned taking care of parents in old age (48\%), compassion towards (cuddly) animals (44\%), the Law of Karma (38\%/37\%), not wanting to kill any animal (35\%), valuing a calm mind (33\%), having respect for those worthy of respect $(41 \%)$ or those who had previously given them special help (32\%), the subjectivity of happiness (33\%) and generosity to the poor and needy (29\%). 


\begin{tabular}{lccc}
\hline & $\begin{array}{c}\% \\
\text { Not } \\
\text { certain }\end{array}$ & $\begin{array}{c}\% \\
\text { disagree }\end{array}$ \\
\hline I like the way Buddhists train their minds through prayer and meditation & 15 & 78 & 8 \\
I like the Buddhist idea of encouraging people to become friends on & 14 & 78 & 7 \\
Sangha Day & 14 & 78 & 8 \\
It is important for Buddhists to avoid drinking alcohol & 13 & 80 & 7 \\
I respect the way some Buddhists spend time in meditation by becoming & & 77 & 10 \\
monks or nuns & 13 & 80 & 10 \\
I like the way Buddhists offer flowers and incense to statues of Buddha & 11 & 82 & 11 \\
Spending time meditating is a constructive use of one's time & 8 & 82 \\
Spending time as a Buddhist monk benefits the world at large & 8 & 81 & 11 \\
Everything that happens to us in this world is ultimately empty & 6 & 83 & 7 \\
Nirvana is the ultimate peace & 6 & 66 & 7 \\
Every compounded thing is impermanent & & & \\
\hline
\end{tabular}

Table 2 shows the ten value statements which elicited the least agreement amongst nonBuddhists and which potentially represent the values that make a person Buddhist. These concerned Buddhist abstinence from alcohol (14\%), friendship on Sangha Day $(14 \%)$, respecting ordination as a monk or nun $(13 \%)$, the benefit to the world of being a monk $(8 \%)$, meditation $(15 \%)$ and the worth of spending time meditating $(11 \%)$, offering flowers and incense at a Buddhist shrine (13\%), the emptiness (8\%) and impermanence $(6 \%)$ of the world and Nirvana as ultimate peace $(6 \%)$.

\section{Comparisons}

Comparisons were made using the independent variables of sex, age and religious affiliation. $^{17}$ 


\section{Sex Differences}

Table 3 Comparison between male and female pupils

\begin{tabular}{|c|c|c|c|c|}
\hline & $\begin{array}{c}\text { Male \% } \\
\text { Agree }\end{array}$ & $\begin{array}{l}\text { Female \% } \\
\text { Agree }\end{array}$ & $\chi^{2}$ & $\mathbf{p}<$ \\
\hline It is important for Buddhists not to kill any sort of animal & 13 & 25 & 7.25 & .01 \\
\hline $\begin{array}{l}\text { Buddhists are to be admired for their respect for all living } \\
\text { things }\end{array}$ & 15 & 28 & 9.01 & .01 \\
\hline I would not want to kill any sort of animal & 26 & 51 & 21.42 & .001 \\
\hline I consider hunting to be an enjoyable sport $\AA$ & 26 & 3 & 28.20 & .001 \\
\hline It sickens me when cuddly animals are killed & 34 & 62 & 25.43 & .001 \\
\hline I consider fishing to be an enjoyable sport ${ }^{\circledR}$ & 38 & 24 & 7.00 & .01 \\
\hline Everyone should take care of their parents in their old age & 25 & 36 & 4.33 & .05 \\
\hline $\begin{array}{l}\text { I would look after my parents in their old age only if they } \\
\text { asked } \AA\end{array}$ & 24 & 40 & 10.01 & .01 \\
\hline $\begin{array}{l}\text { I would look after my parents in their own home in their old } \\
\text { age }\end{array}$ & 43 & 56 & 5.47 & .05 \\
\hline $\begin{array}{l}\text { It is important for Buddhists to look after their parents in their } \\
\text { old age }\end{array}$ & 21 & 31 & 4.52 & .05 \\
\hline $\begin{array}{l}\text { It is important for Buddhists to have respect for those worthy } \\
\text { of respect }\end{array}$ & 14 & 25 & 6.87 & .01 \\
\hline $\begin{array}{l}\text { Some people who have helped us a lot deserve our special } \\
\text { respect }\end{array}$ & 24 & 46 & 19.10 & .001 \\
\hline It is necessary for us to share what we have with others & 19 & 36 & 13.09 & .001 \\
\hline $\begin{array}{l}\text { It is necessary for us to give support to the poor and needy } \\
\text { respect Buddhists for giving food and money to their }\end{array}$ & 21 & 44 & 21.86 & .001 \\
\hline monks & 17 & 32 & 10.46 & .01 \\
\hline What goes around comes around & 29 & 53 & 20.57 & .001 \\
\hline $\begin{array}{l}\text { If a person does good deeds, good things come back to } \\
\text { them }\end{array}$ & 29 & 50 & 15.07 & .001 \\
\hline $\begin{array}{l}\text { I think it is okay to drink in moderation (not so much you are } \\
\text { drunk)® }\end{array}$ & 32 & 60 & 26.89 & .001 \\
\hline I would drink only to be sociable ${ }^{\circledR}$ & 18 & 34 & 12.12 & .001 \\
\hline $\begin{array}{l}\text { Heaven and hell exist as places where people can be } \\
\text { reborn } \\
\text { I respect the Buddhist idea that understanding is more }\end{array}$ & 13 & 21 & 3.96 & .05 \\
\hline important than belief & 16 & 29 & 7.95 & .01 \\
\hline $\begin{array}{l}\text { Whether we enjoy life or hate it depends on how we see the } \\
\text { world }\end{array}$ & 27 & 43 & 8.71 & .01 \\
\hline $\begin{array}{l}\text { I think the Buddhist idea of having a calm mind is a good } \\
\text { one }\end{array}$ & 26 & 45 & 12.73 & .001 \\
\hline $\begin{array}{l}\text { I respect the way some Buddhists spend time in meditation } \\
\text { by becoming monks or nuns }\end{array}$ & 10 & 19 & 6.18 & .05 \\
\hline $\begin{array}{l}\text { Like how Buddhists offer flowers and incense to Buddha } \\
\text { statues }\end{array}$ & 10 & 20 & 7.14 & .01 \\
\hline $\begin{array}{l}\text { I like the Buddhist idea of encouraging people to become } \\
\text { friends on Sangha Day }\end{array}$ & 11 & 20 & 5.12 & .05 \\
\hline
\end{tabular}

Generally speaking, the psychology of religion has found that female subjects are more positive on scales of attitude to religion (Hood et al. 2009, 152). The finding for adolescent attitude to Buddhism by contrast, was that in 24 of 49 items, there was no significant difference between males and females. Nevertheless, the remainder of values statements showed a stronger level of female agreement in accordance with the usual expectations for religious values. Items where a significant difference between males 
and females was found according to a Pearson Chi-squared test (two-tailed) are shown in Table 3 above. In some Buddhist and more general values including respect for living beings, care of parents in old age and respect for those worthy of respect, generosity, the Law of Karma and Buddhist beliefs (heaven \& hell, understanding being more important than belief, subjectivity of happiness, advantages of a calm mind, value of ordination, devotional offering and encouraging friendship on Sangha Day) females showed a more positive attitude. Only in the case of moderate or sociable drinking (which were in any case reverse-coded statements, contradicting Buddhist values) did the males have a significantly higher level of agreement.

\section{Age Differences}

Table 4 Comparison between Year 9 and Year 10 pupils

\begin{tabular}{|c|c|c|c|c|}
\hline & $\begin{array}{l}\text { Y9\% } \\
\text { agree }\end{array}$ & $\begin{array}{l}\text { Y10\% } \\
\text { agree }\end{array}$ & $\chi^{2}$ & $p<$ \\
\hline It is okay to drink as much alcohol as you want ${ }^{\circledR}$ & 25 & 34 & 3.46 & .05 \\
\hline If you are a Buddhist it is important to avoid drinking alcohol & 31 & 14 & 12.72 & .001 \\
\hline I would avoid drinking alcohol under any circumstances & 22 & 13 & 4.60 & .05 \\
\hline $\begin{array}{l}\text { Spending time as a Buddhist monk is beneficial to the world at } \\
\text { large }\end{array}$ & 11 & 4 & 5.40 & .05 \\
\hline Everything that happens to us in this world is ultimately empty & 11 & 4 & 4.67 & .05 \\
\hline If you are Buddhist it is important to spend time meditating & 31 & 19 & 5.78 & .05 \\
\hline $\begin{array}{l}\text { The Buddhist idea of reincarnation (being reborn) makes } \\
\text { sense }\end{array}$ & 19 & 8 & 7.63 & .01 \\
\hline $\begin{array}{l}\text { I would not want to kill any sort of animal } \\
\text { If you are a Buddhist it is important to have respect for those }\end{array}$ & 39 & 28 & 4.45 & .05 \\
\hline $\begin{array}{l}\text { worthy of respect } \\
\text { I would look after my parents in their own home in their old }\end{array}$ & 46 & 33 & 5.58 & .05 \\
\hline 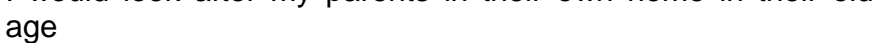 & 53 & 40 & 5.63 & .05 \\
\hline I would drink only to be sociable ${ }^{\circledR}$ & 27 & 18 & 4.09 & .05 \\
\hline It is possible to reach salvation only though the help of God® & 16 & 6 & 7.52 & .01 \\
\hline
\end{tabular}

The expected finding when correlating age against attitude to religion is that attitude should become less positive with age (Francis 2001b, 81). However, for questions concerning attitude to Buddhism, the age difference between Year 9 and Year 10 pupils made no significant difference for 37 of the 49 items. The exceptions to this are shown in Table 4 above, where younger children had a more positive attitude to value 
statements in the case of avoiding alcohol, ordination, the ultimate emptiness of the world, meditation, reincarnation, not killing animals, respecting those worthy of respect, looking after parents in old age and the non-Buddhist values of sociable drinking, and salvation through God. Older children had a higher level of agreement than the younger ones only in the case of consuming of as much alcohol as they liked - which was in any case, a reverse-coded statement. Buddhist value statements therefore conformed with the usual expectation in attitude toward religion measurements of attitude becoming less positive with age.

\section{Differences by religious affiliation}

\section{Table 5. Comparison by religious affiliation}

\begin{tabular}{|c|c|c|c|c|c|}
\hline & $\begin{array}{l}\text { no } \\
\text { religion } \\
\text { \% agree }\end{array}$ & $\begin{array}{l}\text { Dharmic } \\
\% \text { agree }\end{array}$ & $\begin{array}{l}\text { Abrahamic } \\
\% \text { agree }\end{array}$ & $\chi^{2}$ & $\mathbf{p}<$ \\
\hline $\begin{array}{l}\text { Some people who have helped us a lot deserve our } \\
\text { special respect }\end{array}$ & 40 & 27 & 27 & 6.12 & .05 \\
\hline $\begin{array}{l}\text { I respect the Buddhist idea that understanding is } \\
\text { more important than belief }\end{array}$ & 28 & 14 & 16 & 7.98 & .05 \\
\hline $\begin{array}{l}\text { The Buddhist idea of reincarnation (being reborn) } \\
\text { makes sense }\end{array}$ & 22 & 14 & 11 & 6.47 & .05 \\
\hline stories $\AA$ & 13 & 4 & 5 & 7.31 & .05 \\
\hline I would drink only to be sociable $®$ & 32 & 14 & 23 & 9.69 & .01 \\
\hline It is okay to drink as much alcohol as you want ${ }^{\circledR}$ & 42 & 9 & 21 & 20.77 & .001 \\
\hline $\begin{array}{l}\text { I would avoid drinking alcohol under any } \\
\text { circumstances }\end{array}$ & 12 & 36 & 21 & 9.23 & .05 \\
\hline $\begin{array}{l}\text { Spending time meditating is a constructive use of } \\
\text { one's time }\end{array}$ & 12 & 32 & 9 & 9.87 & .01 \\
\hline $\begin{array}{l}\text { I would find an old peoples' home for my parents in } \\
\text { their old age }{ }^{\circledR}\end{array}$ & 20 & 59 & 29 & 14.55 & .01 \\
\hline The Buddhist Noble Eightfold Path seems a very & 18 & 32 & 12 & 716 & 05 \\
\hline Nirvana is the ultimate peace & 10 & 9 & 3 & 6.93 & .05 \\
\hline $\begin{array}{l}\text { I respect Buddhists for giving food and money to } \\
\text { their monks }\end{array}$ & 30 & 27 & 18 & 6.64 & .05 \\
\hline
\end{tabular}

Analysis of attitude results by religious affiliation (where limited numbers allowed only a three way division into 'No Religion', Dharmic and Abrahamic religions) showed significant polarization of opinion [see Table 5 above] on only 12 of the 49 questions asked. 
The Dharmic group of religions (Hinduism and Sikhism) seemed to resemble Buddhism particularly closely in its attitude to abstaining from alcohol, meditation as a constructive use of one's time, caring for parents in an old people's home and the value of the Noble Eightfold Path. On the contrary, it was the Abrahamic religions (Christianity, Islam and Judaism) that differed most from Buddhist attitudes by not agreeing with Nirvana or the support of Buddhist monks. By comparison, the nonreligious favoured Buddhist attitudes more than religious affiliates by being keener on belief based on understanding, reincarnation and respect for those worthy of respect.

\section{Part 3: Discussion}

The present article has been a study in discriminative validity for Buddhist values. The study admittedly depends on the assumption that it is reasonable to extrapolate between 'attitude toward Buddhism' and 'Buddhist attitude'. There remains a possibility however, that the distinction between having a positive attitude to Buddhism (as a nonBuddhist) and having Buddhist attitudes (as a Buddhist) may be larger than anticipated - in consequence of which the article title retains the word 'preliminary'. Nonetheless, the study has produced noteworthy outcomes on two fronts - possible new understanding of Buddhist religiosity and support for policy and practice enactable in contexts where non-Buddhists need to be informed about Buddhism in order to give a positive attitude. 


\section{New understanding of Buddhist religiosity}

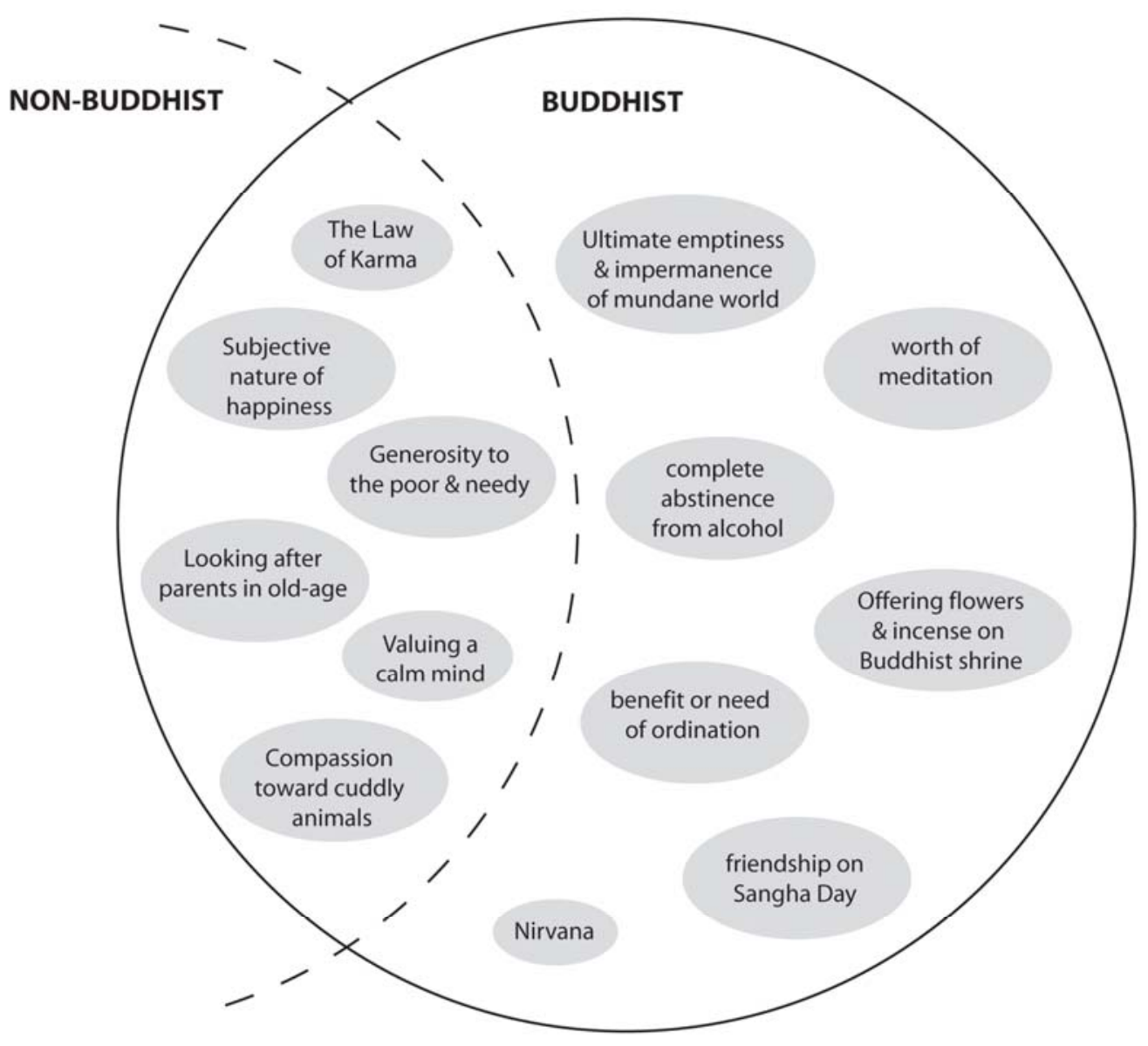

\section{Figure 1. Buddhist Values shared with non-Buddhists}

Figure 1 is a graphic comparison of 'Buddhist' values that are potentially exclusive to Buddhists and those that overlap with non-Buddhists, combining the results from Tables 1 and 2. The figure maps the values boundaries of self-identified religious affiliation. Aspects of Buddhism that at face value might seem representative of Buddhism, upon experimentation turned out not to be exclusive to Buddhism (in terms of concept validity) and therefore would be unreliable as identifiers of Buddhist religiosity for future research. Values such as valuing a calm mind or the Law of Karma - where face validity might lead one to assume that one is dealing with features of Buddhist 
religiosity - were actually shared by adolescents of a non-Buddhist sample. It would appear that few values that we might associate with Buddhists are exclusive to Buddhism - but if a person were to lack these few items from their 'values footprint' it would correspond with 'what makes one not a Buddhist'. There is some support from this study for what Khyentse $(2007,4)$ claims - especially putting store by the belief that all things are impermanent and empty.

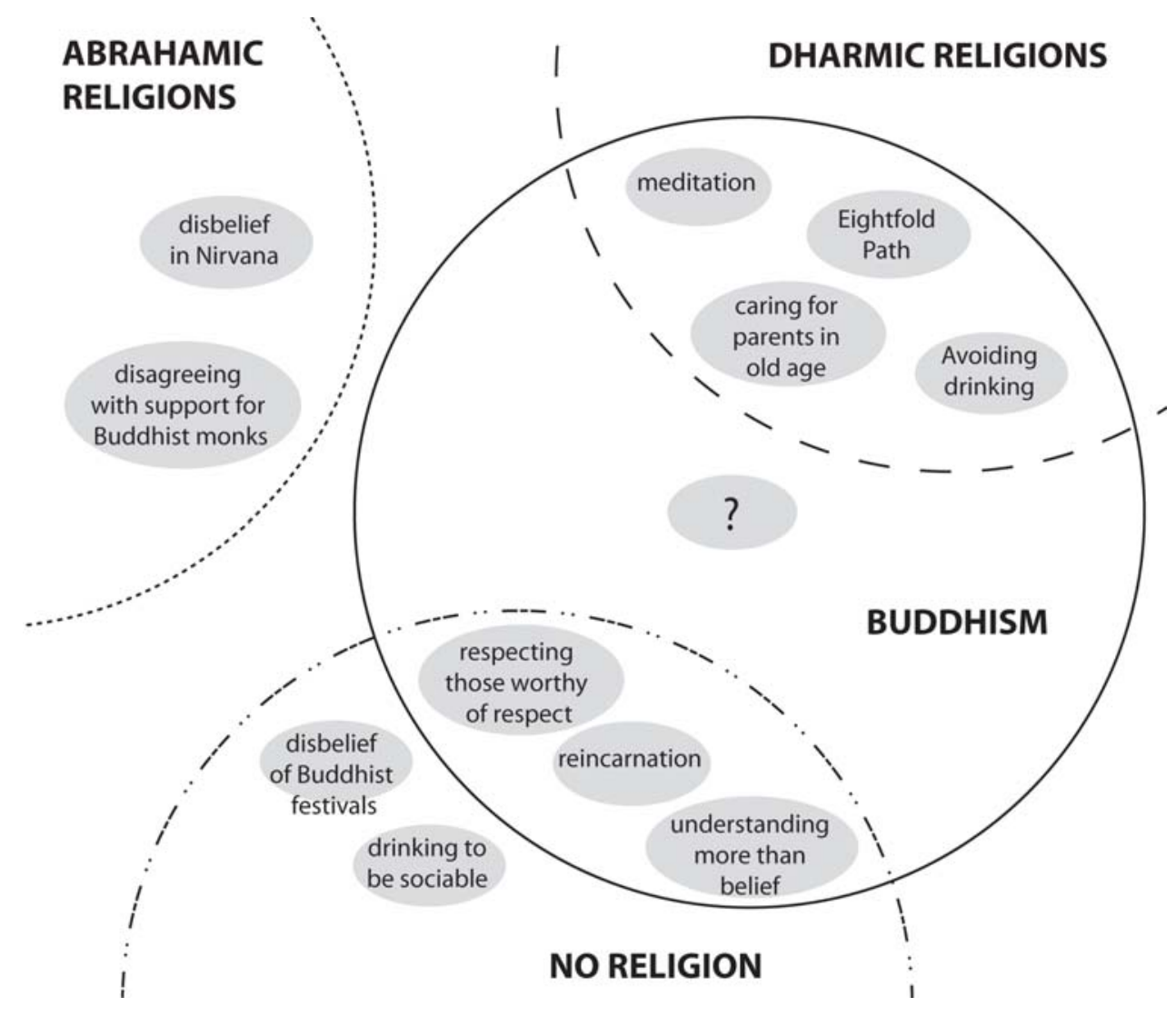

Figure 2. Buddhist values overlapping with non-Buddhists of self-assigned groups

Figure 2 analyses the 'Buddhist' values overlapping with non-Buddhists in terms of self-assigned religious group. The figure shows how conceptually difficult it is to identify exclusively Buddhist values. It would seem instead that religious identity including that of Buddhism has fuzzy boundaries which may indicate Buddhist identity 
being many-layered. At the very minimum, the layers of 'tradition', 'group' and 'individual' identified by Jackson $(1997,65)$ would seem relevant here - a perspective that would take the understanding of Buddhist values beyond the essentialisms of comparative religion. Removing the values shared by the Dharmic religions of Figure 2 from the Buddhist values of Figure 1 leaves offering flowers \& incense, emptiness, impermanence, Nirvana, Sangha Day and ordination - which might indicate a starting place for the elucidation of exclusively Buddhist values in future research. Alternatively, it may be that the Buddhist identity exists as a particular combination of values - a possibility testable by quantitative methods of a large enough sample of Buddhist participants could be surveyed by multifactorial analysis.

Furthermore, in terms of sex, affinity for Buddhist attitudes seemed to be more affective for girls. Age seems to have a smaller impact on enthusiasm for Buddhist values than would be expected in relation to values from other religions. The findings also help avoid stereotyping adolescents (emancipatory) - especially those of no religious affiliation as apathetic toward religious values - which is what tends to happen in the absence of information or if the wrong questions are asked or if the research is not grounded/bottom-up. A direct outcome of this research is that we see that religious apathy is a myth - as adolescents find Buddhism relatively exciting whereas other religions may lead to boredom with education about religion (Thanissaro 2011a, 800).

\section{Support for policy that is enactable}

This study has concerned itself with Buddhism through the eyes of non-Buddhists and has particular relevance in situations where Buddhism needs to be taught in a nonBuddhist context - contexts which might include education about religion or community awareness initiatives in a religiously plural society. Experimental outcomes 
suggest that Buddhist values particularly commend themselves to be widely taught amongst non-Buddhists and the way Buddhism is presently taught in non-Buddhist contexts may need modification.

Buddhism would appear accessible in non-Buddhist contexts because it causes relatively low polarization of opinion for those of other religions, appeals to both sexes and causes enthusiasm to drop away more slowly with age than for other religions. Given that values from a variety of religions need to be taught in the plural classroom, Buddhist values may provide a useful resource for teachers, since 'awareness of shared values' is considered by the Qualifications and Curriculum Authority (QCA) as one of the keys to developing the Spiritual, Moral, Social and Cultural (QCA 1998, 23). As this research has highlighted many shared values, these could be put to relevant use in the classroom, especially in such applications as teaching responsibility toward alcohol. Also in terms of age, as there does not seem to be such a dramatic decline in enthusiasm for schoolchildren studying Buddhism compared to other religions, this would seem to commend the teaching of Buddhism for schoolchildren of higher age ranges.

Ways in which the teaching of Buddhism in a non-Buddhist context could helpfully be modified would be to avoid over-intellectualizing the subject and by contrast to include more affective content and narratives. This research indicates that the comparative religions framework of artefacts, objects of faith and western intellectual understanding of Buddhism in general had missed the point about many aspects of Buddhism that make it unique as a religion. If, as this study suggests, it is true that males and females are drawn to Buddhism by different facets, females favouring more affective aspects such as compassion, filial piety, gratitude, generosity, friendship, the Law of Karma and devotions, it would be more effective when introducing Buddhism to 
non-Buddhists to give a good selection of both affective and intellectual aspects, as previously the affective facets have been neglected (Thanissaro $2011 \mathrm{~b}, 70$ ).

\section{Suggestions for further research}

It would be suggested that future researchers expand the sample size, since this study is based on a relatively small sample of London adolescents meaning results may be at the most indicative of trends in the UK or further afield. Buddhist-affiliated adolescents need to be included in future studies as a question mark remains concerning the sort of values that are exclusively Buddhist. If future research can extend the enquiry to Buddhists themselves, the question of 'What makes a person Buddhist?' could more confidently be answered. Further clarity in this respect could also be gained by drawing on additional qualitative sources of triangulation which might include issues raised by Buddhists as important to their practice (e.g. Loundon 2001; 2006) and undertaking focus groups with Buddhists to rank their own values in order of priority. Correlating religious involvement of Buddhists with their attitudes to Buddhist value statements has not been possible in the present study - but for research in this area to progress, it will become necessary to gain an idea of the values of Buddhists who are more or less involved with their own religion, in terms of daily practice, temple attendance or other possible indicators of Buddhist piety. To test whether values differences can be attributed to group or tradition larger numbers would need to be sampled to make analysis possible in terms of ethnic group and Buddhist denomination.

Finally, without quantitative methods none of the research described here would have been possible and this methodological style is therefore commended as a useful for the wider study of Buddhism and Buddhists, with the provisos mentioned earlier of being properly triangulated with qualitative approaches to the subject. 


\section{APPENDIX 1: 49 Buddhist Attitude Statements in decreasing order of popularity}

1. I would look after my parents in their own home in their old age

2. It sickens me when cuddly animals are killed

3. I think it is okay to drink in moderation (not so much you are drunk)®

4. If you are a Buddhist it is important to have respect for those worthy of respect

5. What goes around comes around

6. If a person does good deeds, good things will come back to them

7. Whether we enjoy life or hate it depends on how we see the world

8. I think the Buddhist idea of having a calm mind is a good one

9. I consider fishing to be an enjoyable sport ${ }^{\circledR}$

10. I would not want to kill any sort of animal

11. Some people who have helped us a lot deserve our special respect

12. I would look after my parents in their old age only if they asked ${ }^{\circledR}$

13. It is necessary for us to give support to the poor and needy

14. Everyone should take care of their parents in their old age

15. I would not want to look after my parents in their old age ${ }^{\circledR}$

16. I would find an old peoples' home for my parents in their old age ${ }^{\circledR}$

17. It is okay to drink as much alcohol as you want ${ }^{\circledR}$

18. If you are Buddhist it is important to spend time meditating

19. It is necessary for us to share what we have with others

20. If you are a Buddhist it is important not to kill any sort of animal

21. If you are a Buddhist it is important to avoid drinking alcohol

22. If you are a Buddhist it is important to look after your parents in their old age

23. I would drink only to be sociable ${ }^{\circledR}$

24. It is important for Buddhists to look after their parents in their old age

25. I respect Buddhists for giving food and money to their monks

26. I find it inspiring to hear Buddhist stories

27. I respect the Buddhist idea that understanding is more important than belief

28. I think it is justified to kill animals if they are pests ${ }^{\circledR}$

29. Buddhists are to be admired for their respect for all living things

30. I would avoid drinking alcohol under any circumstances

31. I consider hunting to be an enjoyable sport ${ }^{\circledR}$

32. It is important for Buddhists to have respect for those worthy of respect

33. It is important for Buddhists not to kill any sort of animal

34. Heaven and hell exist as places where people can be reborn

35. The Buddhist Noble Eightfold Path seems a very good way to achieve happiness

36. It is important for Buddhists to spend time meditating

37. The Buddhist idea of reincarnation (being reborn) makes sense

38. I like the way Buddhists train their minds through prayer and meditation

39. I like the Buddhist idea of encouraging people to become friends on Sangha Day

40. It is important for Buddhists to avoid drinking alcohol

41. I respect the way some Buddhists spend time in meditation by becoming monks or nuns

42. I like the way Buddhists offer flowers and incense to statues of Buddha

43. It is possible to reach salvation only though the help of God®

44. Spending time meditating is a constructive use of one's time

45. I think Buddhist festivals are based on fairy-stories ${ }^{\circledR}$

46. Spending time as a Buddhist monk is beneficial to the world at large

47. Everything that happens to us in this world is ultimately empty

48. Nirvana is the ultimate peace

49. Every compounded thing is impermanent

( I Indicates reverse coded statements 


\section{References}

Adamson, J. 2003. 'Challenging beliefs in teacher development: potential influences of Theravada Buddhism upon Thais learning English', Asian EFL Journal, 5, no. 3, $1-21$.

Andolina, M.W., K. Jenkins, S. Keeter and C. Zukin. 2002. 'Searching for the Meaning of Youth Civic Engagement: Notes from the Field', Applied Developmental Science, 6, no. 4, 189-195.

Assanangkornchai, S., K.M. Conigrave and J.B. Saunders. 2002. 'Religious beliefs and practice and alcohol use in Thai men', Alcohol and Alcoholism, 37, no. 2, 193197.

Banks, J.A. 2006. 'Improving Race Relations in Schools: From Theory and Research to Practice', Journal of Social Issues, 62, no. 3, 607-614.

Berliner, D.C. 2002. 'Comment: educational research: the hardest science of all', Educational Researcher, 31, no. 8, 18-20.

Brewer, J.D. 2000. Ethnography, Buckingham: Open University Press.

Carnap, R. 1966. 'The rejection of metaphysics', in M. Weitz (ed) 20th-century philosophy: The analytic tradition, New York: Free Press, pp.206-219.

Chakravarti, S.S. 1991. Hinduism: A Way of Life, New Delhi: Motilal Banarsidass.

Chamorro-Premuzic, T. 2007. Personality and Individual Differences, Oxford: BPS Blackwell.

Choompolpaisal, P. 2008. 'Constructive Constructs: Unravelling the Influence of Weber's Sociology on Theravada Studies since the 1960's', Contemporary Buddhism, 9, no. 1, 7-51.

Clifford, J. 1997. 'Spatial practices: fieldwork, travel, and the disciplining of anthropology', in A. Gupta and J. Ferguson (ed) Anthropological locations: boundaries and ground of a field science, Berkeley, CA: University of California Press, pp.185-222.

Clifford, J. and G.E. Marcus. 1986. Writing Culture: The Poetics and Politics of Ethnography, Berkeley, CA: University of California Press.

Cohen, L., L. Manion and K. Morrison. 2007. Research Methods in Education, London: Routledge.

Cooper, C. 2002. Individual Differences, London: Hodder Education.

Crosby, K. 2008. 'Changing the landscape of Theravada studies', Contemporary Buddhism, 9, no. 1, 1-6.

Cush, D. 1996. 'British Buddhism and the New Age', Journal of Contemporary Religion, 11, no. 2, 195-208.

de_Silva, P. 1996. 'Buddhist psychology and implications for treatment', in D. Bhugra (ed) Psychiatry and Religion: Context, Consensus and Controversies, London: Routledge, pp.112-124.

Delmonico, N. 2004. 'The history of Indic Monotheism and Modern Chaitanya Vaishnavism: Some Reflections', in M. Ekstrand (ed) The Hare Krishna Movement: The Postcharismatic Fate of a Religious Transplant, New York: Columbia University Press, pp.31-34.

Denzin, N.K. 1978. The Research Act: A Theoretical Introduction to Sociological Methods, New York: McGraw-Hill.

Erickson, F. and K. Gutierrez. 2002. 'Comment: culture, rigor, and science in educational research', Educational Researcher, 31, no. 8, 4-14. 
Fane, R.S. 1999. 'Is Self-assigned Religious Affiliation Socially Significant?' in L. J. Francis (ed) Sociology, Theology and the Curriculum, London: Cassell, pp.113124.

Francis, L.J. 1978. 'Attitude and longitude: a study in measurement', Character Potential: a record of research, 8, 119-130.

Francis, L.J. 2001a. 'Religion and values: a quantitative perspective', in L. J. Francis, J. Astley and M. Robbins (ed) The Fourth $R$ for the Third Millennium: Education in Religion and Values for the Global Future, Dublin: Lindisfarne, pp.47-78.

Francis, L.J. 2001b. The Values Debate: a voice from the pupils, London: Woburn Press.

Francis, L.J. 2009. 'Comparative Empirical Research in Religion: Conceptual and Operational Challenges within Empirical Theology', in L. J. Francis, M. Robbins and J. Astley (ed) Empirical Theology in Texts and Tables: Qualitative, Quantitative and Comparative Perspectives, Leiden: Brill, pp.127152.

Francis, L.J., Y.R. Santosh, M. Robbins and S. Vij. 2008. 'Assessing attitude toward Hinduism: The Santosh-Francis Scale', Mental Health, Religion and Culture, 11 , no. 6, 609-621.

Furlong, J. 2004. 'BERA at 30: have we come of age?' British Education Research Journal, 30, no. 3, 343-358.

Garrison, J.W. 1986. 'Some Principles of Postpositivistic Philosophy of Science', Educational Researcher, 15, no. 9, 12-18.

Glaser, B.G. and A.L. Strauss. 1967. Discovery of Grounded Theory: Stategies for Qualitative Research, Mill Valley, CA: Sociology Press.

Glock, C.Y. 1962. 'On the study of religious commitment', Religious Education, 57, no. Research Supplement, 98-110.

Hartas, D. 2010. Educational Research and Inquiry: Qualitative and Quantitative Approaches, London: Continuum.

Hofstede, G. 2001. Culture's Consequences: Comparing Values, Behaviors, Institutions, and Organizations Across Nations, Thousand Oaks, CA: Sage.

Hood, R.W., P.C. Hill and B. Spilka. 2009. The Psychology of Religion: An Empirical Approach, New York: The Guilford Press.

Hubbard, J. and P.L. Swanson, ed. (1997), Pruning the Bodhi Tree: The Storm over Critical Buddhism (Honolulu: University of Hawai'i Press).

Jackson, R. 1997. Religious Education: An Interpretive Approach, London: Hodder and Stoughton.

Jackson, R. and E.M. Nesbitt. 1993. Hindu Children in Britain, Stoke on Trent: Trentham.

Kay, W.K. and D.L. Smith. 2001. 'Quantitative Work from the Inside: Numbers, Problems and Policy', British Journal of Religious Education, 23, no. 3, 177187.

Kelly, G.J. 2006. 'Epistemology and Educational Research', in J. L. Green, G. Camelli and P. B. Elmore (ed) Handbook of complementary methods in education research, Mahwah, NJ: Lawrence Erlbaum, pp.33-55.

Kemp, S. and J. Holmwood. 2003. 'Realism, regularity and social explanation', Journal for the Theory of Social Behaviour, 33, no. 2, 165-187.

Khyentse, D.J. 2007. What Makes You Not a Buddhist, Boston, MA: Shambala.

Kluckhohn, C., H.A. Murray and D.M. Schneider. 1953. Personality in nature, society, and culture, New York: Knopf. 
Loundon, S. 2001. Blue Jean Buddha: Voices of Young Buddhists, Somerville, MA: Wisdom Publications.

Loundon, S. 2006. The Buddha's Apprentices: More Voices of Young Buddhists, Somerville, MA: Wisdom Publications.

Maltby, J., L. Day and A. Macaskill. 2010. Personality, Individual Differences and Intelligence, Harlow: Pearson Education.

Pennington, D. 2003. Essential Personality, London: Arnold.

Popper, K.R. 1963. Conjectures and Refutations: the growth of scientific knowledge, New York: Harper \& Row.

Pracharart, P.L.P. 2004. The British Practice of Theravada Buddhism, Unpublished PhD Dissertation: Department of Theology, University of Birmingham.

Pupatana, S. 2000. 'The Development of Peace through the Process of Morality', Chung-Hwa Buddhist Journal, 13, no. 2, 613-634.

QCA. 1998. Guidance for Schools: The promotion of pupils' spiritual, moral, social and cultural development, London: QCA.

Rogers, P. 2009. Ultimate Truth, Book 1, Bloomington, IN: Authorhouse.

Scotton, B.W. 1998. 'Treating Buddhist Patients', in H. G. Koenig (ed) Handbook of Religion and Mental Health, New York: Academic Press, pp.263-270.

Smart, N. 1987. Religion and the Western Mind, New York: State University of New York Press.

Smart, N. 1992. The World's Religions, Cambridge: Cambridge University Press.

Smith, D.L. and W.K. Kay. 2000. 'Religious Terms and Attitudes in the Classroom (Part 2)', British Journal of Religious Education, 22, no. 3, 181-191.

Smith, W.C. 1981. Towards a World Theology: Faith and the Comparative History of Religion, Maryknoll, NY: Orbis.

SPSS_Inc. 1988. SPSS User's Guide, 2nd Edition, New York: McGraw-Hill.

Thananart, M. 2000. 'Longitudinal Study of Psychosocial Changes among Thai Adolescents participating in a Buddhist Ordination Program for Novices', Adolescence, 35, 285-293.

Thanissaro, P.N. 2010a. "Heaven starts at your parent's feet": Adolescent bowing to parents and associated spiritual attitudes', International Journal of Children's Spirituality, 15, no. 4, 295-305.

Thanissaro, P.N. 2010b. 'Home shrines in Britain and associated spiritual values', Journal of Beliefs \& Values, 31, no. 3, 353-357.

Thanissaro, P.N. 2010c. Religious Education and Attitudes to Buddhism \& Sikhism, Unpublished MA Dissertation: University of Warwick.

Thanissaro, P.N. 2010d. 'Teaching Buddhism in Britain's schools: redefining the insider role', Contemporary Buddhism, 11, no. 1, 69-84.

Thanissaro, P.N. 2011a. 'Measuring attitude towards Buddhism and Sikhism: Internal consistency reliability for two new instruments', Mental Health, Religion \& Culture, 14, no. 8, 797-803.

Thanissaro, P.N. 2011b. 'A preliminary assessment of Buddhism's contextualisation to the English RE classroom', British Journal of Religious Education, 33, no. 1, 61-74.

Tooley, J. and D. Darby. 1998. Education Research: A Critique, London: Ofsted.

Tori, C.D. and M. Bilmes. 2002. 'Multiculturalism and Psychoanalytic Psychology: The Validation of a Defense Mechanisms Measure in an Asian Population', Psychoanalytic Psychology, 19, 701-721.

Wallace, B.A. 2007. Contemplative Science: Where Buddhism and Neuroscience Converge, New York: Columbia University Press. 
Yogo, R. 2001. Jung and Buddhism: a hermeneutical engagement with the Tibetan and Zen Buddhist traditions, Unpublished PhD Dissertation: University of Kent at Canterbury.

\section{Notes}

1 The author would like to thank Dr. Mandy Robbins (Glyndwor University) for supervision of the original research, Denise Chaplin (RE advisor to Southwark) and Greenwich SACRE for facilitation of schools access, Revd. Canon Prof. Leslie J. Francis (University of Warwick), Prof. Steve Strand (University of Warwick), Dr. Andrew Skilton (SOAS, University of London) and the anonymous reviewers for critique and encouragement, Phra Kru Sangharak Veera Virandharo, Kannika Parker, Anuchit Treerattanajutawat, Bhuzaneezah Boonthucksa and Apassara Sangrungreang for administrative assistance and the Teachers Development Agency and Dhammakāya International Society of the United Kingdom which co-sponsored the cost of this research.

2 www.brin.ac.uk

3 At the time of publication, a selection of such journals would include Archiv für Religionspsychologie, Journal for the Scientific Study of Religion, Pastoral Psychology, Journal of Empirical Theology and Review of Religious Research

4 Judaism, Sikhism and Hinduism are also underrepresented in quantitative research

5 For the purpose of most significance testing a sample of more than one hundred participants would be preferable.

6 Doctrine, Mythology, Ethics, Ritual, Experience, Institution, Material

7 Although some limitations may be experienced when the scale is applied to certain denominations of Christianity outside the 'mainstream', pers. comm. (Francis 6 June 2011)

8 Phrenology is a historical example where this distinction was particularly pertinent.

9 It appears that the Hindu scale was constructed by effecting a transposition of the terms for objects of faith from the Christian scale by retaining the word 'God' [not allowing for Hindu views that span a wide range of theistic beliefs], and simply substituting 'Hindu rituals' for 'Church service' and 'Hindu scriptures' for 'the Bible'.

10 Hindu beliefs may typically be diverse as monotheism, polytheism, panentheism, pantheism, monism, atheism and agnosticism (Chakravarti 1991, 71; Rogers 2009, 109).

11 Perhaps reflecting King Pāyāsi's comeuppance in the early Buddhist scriptures (D.ii.316f.), in his efforts to study metaphysics empirically.

12 All things are impermanent; all emotions bring pain and suffering; all phenomena are empty and illusory, and; enlightenment is above all concepts and a release from delusion.

13 A flag said to flap in breeze not because of the movement of the flag or the breeze but because of movement in the mind of the perceiver.

14 It was not clear whether Smith \& Kay's questions were grounded in the actual experience of Buddhist young people

15 None of the 'other religions' were Buddhist

16 See Appendix 1

17 Correlations with degree of religious involvement such as attendance of a place of worship, frequency of prayer and frequency of reading religious scriptures were omitted since respondents' involvement and the value statements they were responding to were derived from two different religions. Although showing some significant correlations (especially concerning abstinence from alcohol and belief in God) the measures did not link relevantly with previous research. Nonetheless, I have published correlations with two additional indicators of religious involvement, possessing a home shrine and bowing to parents, elsewhere (Thanissaro 2010a; b). 